\title{
Water Hardness Key Element in Choosing Between Washing Efficiency with Enzyme Detergent and the Lifespan of the Washing Machine
}

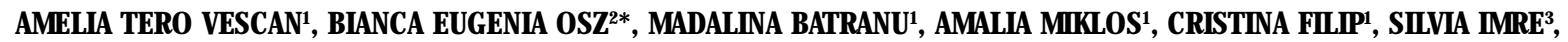 \\ CAMIL EUGEN VARI ${ }^{2}$ \\ 'University of Medicine and Pharmacy, Faculty of Pharmacy, Department of Biochemistry, $38^{\text {th }}$ Gh. Marinescu Str., 540139, Tirgu \\ Mures, Romania \\ 2University of Medicine and Pharmacy, Faculty of Pharmacy, Department of Pharmacology and Clinical Pharmacy, $38^{\text {th }}$ Gh. \\ Marinescu Str., 540139, Tirgu Mures, Romania \\ 3University of Medicine and Pharmacy, Faculty of Pharmacy, Department of Analytical Chemistry and Drug Analysis, $38^{\text {th }} \mathrm{Gh}$. \\ Marinescu Str., 540139, Tirgu Mures, Romania
}

\begin{abstract}
The use of detergents with enzymatic activity is very popular if we consider their real economic advantages - reducing energy and water consumption but also reducing the environmental impact by using more biodegradable components related to organic and inorganic components. The purpose of our study was to evaluate the impact of environmental factors such as the variability of water hardness in the public water supply network and the temperature applied to the amylolytic, lipolytic and proteolytic enzyme activity of 6 detergents available on the market. The determinations were performed by modified methods from the European Pharmacopoeia $8^{\text {th }}$ Edition in determination the enzymatic activity of the pancreas powder. The determinations show a significant influence of increased water hardness on lipase and protease activity in detergent $(p<0.01 *)$ between extreme hardness values, while amylolytic activity does not vary significantly with increasing water hardness.
\end{abstract}

Keywords: enzyme laundry detergent, amylase, lipase, protease, water hardness

Water quality is extremely important for enzymatic activity, as it is a type of catalysis that occurs in an aqueous environment. The three-dimensional protein structure of enzymes is highly dependenton the possibility of hydrogen bonding between active functional groups in the structure of amino acids (hydroxyl groups of serine, tyrosine or threonine or carboxyl groups not included in the peptide bond of aspartic or glutamic acid) or intra / inter-protein chain hydrogen bonding in the case of the á-helix or âsheet structure of the polypeptide chain, all of which are favored by the aqueous medium [1].

Proteases, amylases, lipases and cellulases are enzymes commonly used in detergents to improve their washing properties to reduce the cost of this process - reducing the temperature of the washing process, water consumption and, at the same time, the impact on the environment reducing the concentration of potentially toxic ingredients on the environment [2]. Enzymes produced by biotechnological processes have the advantage of being detergent-compatible enzymes with an optimal temperature different from that in vivo and with maximum activity at a temperature below $37^{\circ} \mathrm{C}$ [3]. Although there have been controversies over time regarding the safety of synthetic detergents on the ecosystem, for over 100 years their use has become part of the routine of the population worldwide without disturbing effects on the environment [4]. This benefit is due to the interest of manufacturers in constantly developing the detergent composition to be as less harmful as possible

Scientific literature offers a variety of studies with the aim to improve the detergent washing properties but also to change their composition to be ecofriendly - reducing the amount of additives used - surfactants, phosphates, their replacement with bio-compounds - enzymes, but also the influence of these additives on the enzymatic activity [5], there are studies on the influence of water hardness on the efficacy of surfactants sodium oleate, linear dodecylbenzene sulfonate or sodium dodecyl sulfate [6, 7], but there are no studies on the modification of the proteolytic, amylolytic and lipolytic enzymatic activity in detergents, depending on the hardness of the water, during a washing cycle in the washing machine.

The use of chelating agents such as ethylenediaminetetraacetic acid (EDTA) and diethylenetriaminepentaacetic acid (DTPA) in the detergent composition is limited because they are not biodegradable and are being replaced by compounds such as nitrilotriacetic acid, ethylenediaminedisuccinic acid and iminodisuccinic acid $[8,9]$.

Water hardness caused by the presence of calcium and magnesium ions, can influence the enzymatic activity, metal ions acting as enzyme modulators - activating effect or, on the contrary, inhibiting effect (poisons) by altering the electrical charges in the active center, becoming more or less capable of binding the substrate, actively participating in oxidation-reduction processes or forming insoluble complexes with the reaction products. On the other hand, metal ions can cause protein-enzyme denaturation by dehydration [10], so the catalytic effect is altered. Therefore, obtaining stable alkaline $\mathrm{pH}$ enzymes over a wider temperature range and a catalytic activity independent of water hardness is one of the desires of the detergent chemical industry [11-13].

Although enzyme detergents are industrially manufactured since the beginning of the last century, they seem to be a future solution to saving the planet's resources (water, electricity, etc.) therefore the purpose of this study is to determine the enzymatic efficacy of detergents with declared enzyme content under the conditions of variable amounts of metallic ions in the washing water, starting from a controversy in the literature: on the one hand they are environmentally friendly by the lower content of chemicals, on the other hand detergent components such as sodium dodecyl sulfates are environmental pollutants 
by denaturing enzymes from living organisms that come into contact with polluted water [14].

Taking in account to all these facts, the aim of the present work was to study if there is any influence of the water hardness on the proteolytic, amylolytic and lipolytic activity of enzymatic detergents, during a cleaning cycle in the washing machine.

\section{Experimental part}

Water samples were obtained from different counties from the public water supply system or water from the hydrophore and used domestically.

Six liquid enzyme detergents on the Romanian market were selected, which were coded as D1-D6.

Determination of the enzymatic activity of detergents was performed by methods described in European Pharmacopoeia $8^{\text {th }}$ Edition for pancreatin powder and adapted for detergent determinations [15].

The standard substance was prepared from $150 \mathrm{mg}$ of pancreatin powder (10,000 units of lipase, 8,000 units amylase, 600 units of protease activity quantified by $\mathrm{Ph}$ Eur. method) of pharmaceutical purity suspended in distilled water so that it was diluted 50 times.

The detergent sample was diluted 100 times as recommended by manufacturers directly in $U_{1}$ Ultra Thermostatic Water Bath with water of differenthardness.

\section{$U_{1}$ Ultra Thermostatic Water Bath}

${ }^{1}$ Determinations were performed using $U_{1}$ Ultra Thermostatic Water Bath (fig. 1) produced by Medingen with the following technical characteristics: power $=650$ W, thermostat, motor $1450 \mathrm{rpm}$ and flow rate $4 \mathrm{~L} / \mathrm{min}$.

Determination of amylolytic activity is based on iodometric titration of excess starch left unmodified in the presence of amylase from the detergent. The detergent was diluted directly into $U$ Ultra Thermostatic Water Bath with water of various hardness, the substrate, $1 \%$ starch

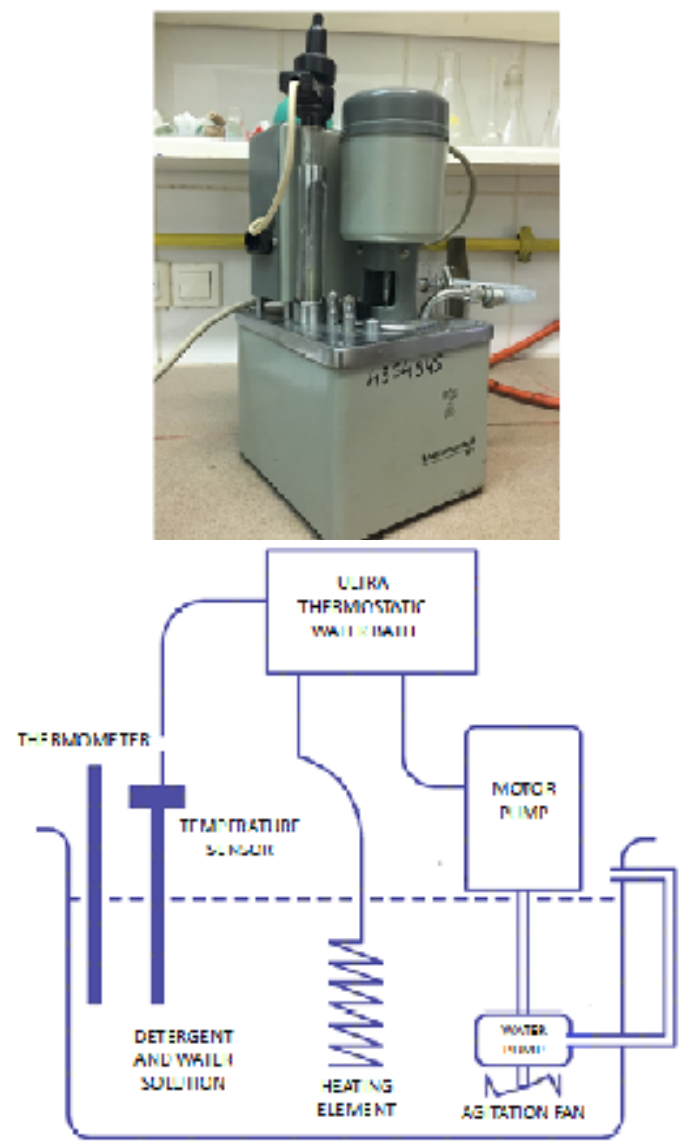

Fig. 1. U Ultra Thermostatic Water Bath was introduced and incubated for $30 \mathrm{~min}$ at $20^{\circ} \mathrm{C}$, as recommended by commercial enzyme-based detergent manufacturers. After incubation in U Ultra Thermostatic Water Bath, $1 \mathrm{M} \mathrm{HCl}$ was added to inhibit enzyme activity and a sample was obtained to which $0.1 \mathrm{M} \mathrm{KI}$ and $0.1 \mathrm{M}$ $\mathrm{NaOH}$ was added and keptin the dark at room temperature for $15 \mathrm{~min}$. The excess of iodine was titrated with $0.1 \mathrm{M}$ $\mathrm{Na}_{2} \mathrm{~S}_{2} \mathrm{O}_{3}$. The activity of a standard pancreatin suspension was determined in the conditions described above.

Determination of proteolytic activity is based on reading the absorbance of a sample, at $275 \mathrm{~nm}$, obtained from hydrolysis of peptide linkages in the casein structure in the presence of detergentenzymes. The detergent was diluted directly into $U$ U Ultra Thermostatic Water Bath with water samples of different hardness and the casein substrate was added.

Determination of the lipolytic activity of detergents was performed by incubating the sample and the standard sample with the substrate (Emulsio Oleosa, Romanian Pharmacopoeia 10th Edition) for $30 \mathrm{~min}$ at $20^{\circ} \mathrm{C}$ and titrating the free fatty acids with $0.05 \mathrm{~N} \mathrm{NaOH}$ solution in the presence of thymolphthalein. The detergent was introduced into $U_{1}$ Ultra Thermostatic Water Bath and diluted with water of various hardness, substrate, oil emulsion was added and incubated for $30 \mathrm{~min}$ at $20^{\circ} \mathrm{C}$. After incubation $96^{\circ}$ ethanol was added to inhibit enzyme activity and samples were obtained and the acidity was titrated with $0.05 \mathrm{~N} \mathrm{NaOH}$ in the presence of thymolphthalein as an indicator. The free acidity of the sample under enzyme inhibition conditions was determined (blank sample). Results obtained were compared to a standard.

Influence of water temperature on enzymatic activity. Detergent samples prepared in distilled water were incubated in $\mathrm{U}$ Ultra Thermostatic Water Bath under the same conditions previously described, at various temperatures $\left(10-90^{\circ} \mathrm{C}\right)$.

\section{Results and discussions}

Water hardness from several water sources was analyzed by a complexonometric method and the values obtained were between $2.82-22.81^{\circ} \mathrm{dH}$. Four water sources with low hardness of $2.82^{\circ} \mathrm{dH}$, medium low $5.23^{\circ} \mathrm{dH}$, medium high $11.51{ }^{\circ} \mathrm{dH}$ and high $22.81^{\circ} \mathrm{dH}$ were selected for analysis. The influence of temperature on enzymatic activity is shown in table 1.

Enzymatic activity increases with increasing temperature up to one point (considered to be the optimal temperature), after which this activity decreases. Detergent manufacturers recommend the use of enzyme detergents at $20^{\circ} \mathrm{C}$, which would reduce electricity consumption. From the graphical representation of enzymatic activity as a function of temperature it is observed that at $20^{\circ} \mathrm{C}$ the enzymes are less active, the highest activity being around $37^{\circ} \mathrm{C}$. Unlike in vivo active enzymes, in the case of genetically engineered enzymes, the enzymatic activity does not decrease drastically as temperature increase, the enzymatic activity does not become 0 not even at temperatures above $60^{\circ} \mathrm{C}$ (fig. 2). We note, however, a significantincrease in the variability of the protease enzyme activity at high temperatures, which can be explained bya direct influence of temperature increase on the structure of the substrate (denaturation of proteins with temperature rise), casein being much more sensitive to temperature increase compared to starch or oily emulsion.

This variability of enzymatic activity with temperature is best described by a $3^{\text {rd }}$ order polynomial equation, which raises the question of interpreting these data - the enzymatic activity should increase with temperature, 


\begin{tabular}{|l|l|l|l|}
\hline $\begin{array}{c}\text { Temperature } \\
\left({ }^{\circ} \mathrm{C}\right)\end{array}$ & \multicolumn{1}{|c|}{$\begin{array}{c}\text { Amylase activity } \\
\text { Average U/L (DSR\%) }\end{array}$} & $\begin{array}{c}\text { Lipase activity } \\
\text { Average U/L (DSR\%) }\end{array}$ & $\begin{array}{c}\text { Protease activity } \\
\text { Average U/L (DSR\%) }\end{array}$ \\
\hline 10 & $57732(4.56)$ & $24012(9.85)$ & $2885(6.77)$ \\
\hline 20 & $65979(6.45)$ & $48325(10.32)$ & $60042(8.78)$ \\
\hline 37 & $164948(5.77)$ & $301265(9.92)$ & $124615(7.73)$ \\
\hline 50 & $74227(9.26)$ & $110237(8.69)$ & $28884(10.82)$ \\
\hline 60 & $49484(7.16)$ & $79365(10.86)$ & $14135(10.78)$ \\
\hline 70 & $41237(9.58)$ & $80549(12.23)$ & $12999(73.26)$ \\
\hline 90 & $40266(10.21)$ & $112365(9.13)$ & $12692(75.35)$ \\
\hline
\end{tabular}

Table 1

THE INFLUENCE OF THE WATER TEMPERATURE ON THE ENZYMATIC ACTIVITY OF DETERGENT D1

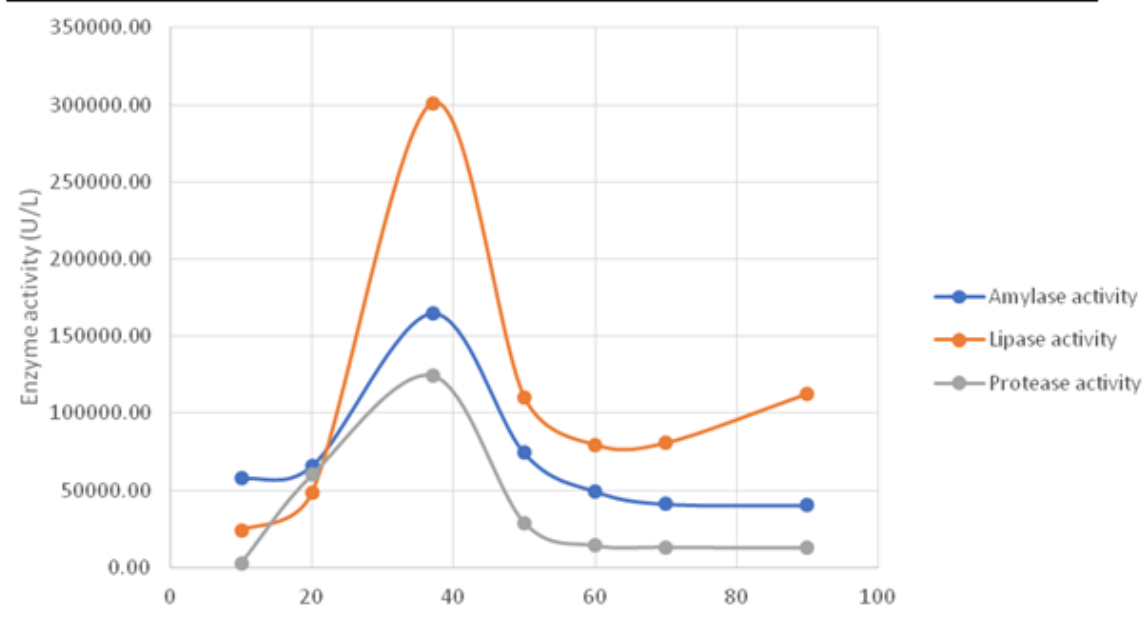

Fig. 2. Temperature influence on enzymatic activity of $D_{1}$

decrease and then increase again. For the mathematical determination of the optimum temperature for enzymatic activity, the order II derived function of the mathematical equation expressing the variation of the enzymatic activity as a function of temperature was calculated. Even though a quadratic equation has two distinct solutions, we must consider that the water temperatures in the public water supply system have positive values and that the optimal temperature values above $50^{\circ} \mathrm{C}$ are biologically improbable. Thus, in the case of amylase, the calculated mathematic value of optimum temperature differs from that in vivo [16] and is $34^{\circ} \mathrm{C}$ and for lipases and proteases is 33 and $27^{\circ} \mathrm{C}$, respectively. Obtaining enzymes with amylolytic activity in genetically modified bacterial cultures provides thermic resistance and a reduced sensitivity to $\mathrm{pH}$ variations, but even in these cases the presence of EDTA chelants in the environment reduces enzymatic activity by up to $22 \%$. A drawback identified by industrial producers is the difficult and expensive isolation and purification of these varieties [17]. Literature data show that lipase activity is maximal at a temperature of $40^{\circ} \mathrm{C}$ and at a $\mathrm{pH}$ between 4.3-7.2. In the case of detergent lipase, maximum catalytic activity is also influenced by the alkaline $\mathrm{pH}$ value in the environment, which can increase the sensitivity of the enzyme to low temperature variations $[18,19]$. Data from the literature show that the activity of proteases of bacterial origin in detergents is optimal in the range of $30-40^{\circ} \mathrm{C}$ and alkaline $p \mathrm{H}(p \mathrm{H}=9$-11) seems to favor the catalytic process $[20,21]$.

Water hardness influence on the amylolytic activity of detergents

The results obtained in determining the activity of the amylases in the detergents are shown in table 2.

Althougn there are differences in the capacity of enzymes in different detergents to hydrolyze starch, the presence of varying amounts of calcium and magnesium ions in the medium does not appear to significantly influence the catalytic activity.

Amylase is a metal enzyme containing calcium ions in the active center, and moreover, a 2013 study by Ghollasi $M$ et al indicates that obtaining isolated enzymes from Bacillus megaterium mutant species to which an additional binding site for calcium ion was introduced by replacing a histidine residue with glutamic acid, exhibited an increased thermostability and a wide range of $\mathrm{pH}$ in which they are active (3.5-9.0), which would be of great importance for the detergent industry [22].

Yadav J $K$ shows that there is a compromise that detergent manufacturers make between increased enzyme activity $\left(\mathrm{Ca}^{2+}\right.$ at low concentrations $1.0-2.0 \mathrm{mM}$ is $\alpha$-amylase activator) and enzyme thermostability $\left(\mathrm{Ca}^{2+}\right.$ at high concentrations is enzyme inhibitor, but in at the same time the enzyme becomes thermoresistant) therefore, as can be seen from figure 3 , enzymatic activity of amylase increases generally with increasing water hardness but at the highest value $\left(22.81^{\circ} \mathrm{dH}\right)$ the activity decreases [23].

Studies demonstrating the influence of calcium ion on á-amylase activity use EDTA to complex calcium, its absence from the environment inactivates enzymes, even in the case of apparently calcium independent amylase, it is supposed to be so strongly bonded to the protein structure that it cannot be removed by EDTA [24].

Binding of calcium ion to the $\alpha$-amylase protein structure increases the thermal stability and against various surfactants and tensioactive substances of the enzyme by reducing the flexibility of the protein structure, therefore there is a hypothesis of saturation of the enzymatic structure with calcium ions a priorito its addition to detergents, which 


\begin{tabular}{|l|l|l|l|l|l|l|}
\hline \multirow{2}{*}{$\begin{array}{c}\text { Water hardness } \\
(\end{array}$} & \multicolumn{6}{|c|}{ Amyl Average U/L (DSR\%) } \\
\cline { 2 - 7 } & $D_{1}$ & $D_{2}$ & $D_{3}$ & $D_{4}$ & $D_{5}$ & $D_{6}$ \\
\hline \multirow{2}{*}{2.82} & 189691 & 329897 & 239175 & 156701 & 230928 & 107216 \\
& $(9.41)$ & $(12.90)$ & $(9.34)$ & $(11.31)$ & $(11.46)$ & $(8.64)$ \\
\hline \multirow{2}{*}{5.23} & 140206 & 329897 & 206186 & 123711 & 206186 & 148454 \\
& $(12.05)$ & $(10.46)$ & $(9.38)$ & $(13.64)$ & $(10.20)$ & $(11.09)$ \\
\hline \multirow{3}{*}{11.51} & 164948 & 373196 & 181443 & 149485 & 247423 & 157732 \\
& $(13.03)$ & $(6.07)$ & $(11.99)$ & $(12.34)$ & $(16.66)$ & $(8.40)$ \\
\hline \multirow{2}{*}{22.81} & 111237 & 330928 & 173195 & 148454 & 214433 & 173196 \\
& $(11.66)$ & $(12.01)$ & $(12.69)$ & $(13.12)$ & $(8.38)$ & $(10.76)$ \\
\hline
\end{tabular}

Table 2

THE INFLUENCE OF WATER HARDNESS ON AMYLASE ACTIVITY OF DIFFERENT DETERGENTS

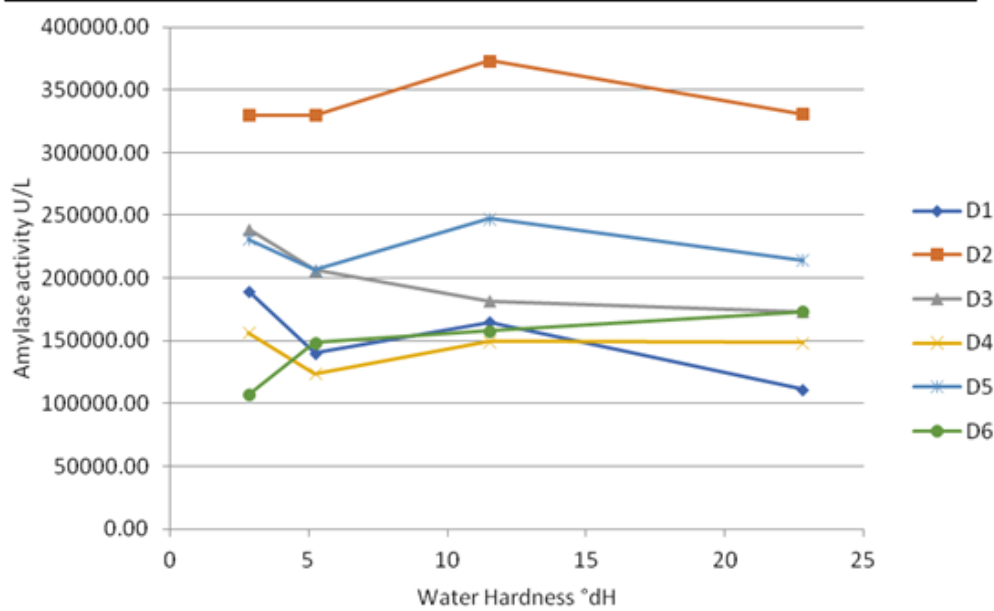

Fig. 3. Water hardness influence on amylolytic enzymatic activity of different detergents

There are statistically significant differences $(p<0.01 *)$ would explain, on the one hand, the low influence of the water hardness on the enzymatic activity and, on the other hand, the 10-fold higher catalytic activity of amylase at $90^{\circ} \mathrm{C}$ than the lipase or the detergent proteases (fig. 3) [25].

Water hardness influence on the lipolytic activity of detergents

The results obtained in the determination of lipase activity are shown in table 3. between the enzymatic activity at extreme values of the water hardness for the detergents $D_{1}, D_{4}, D_{5}$ and $D_{6}$ regarding the lipolytic; $D$, has the highestenzymatic activity and the catalytic activity of lipase in detergents $D_{2}$ and $D_{3}$ is not significantly influenced by the water hardness (fig. 4).

It is well known that lipase is an enzyme activated by calcium ions from the environment because the formation of insoluble salts (soaps) with reaction products, fatty acids, modifies the chemical equilibrium. This problem is

\begin{tabular}{|l|l|l|l|l|l|l|}
\hline \multirow{2}{*}{$\begin{array}{c}\text { Water hardness } \\
\text { ( }\end{array}$} & \multicolumn{5}{|c|}{ Lipase activity } \\
\cline { 2 - 7 } & $\mathrm{D}_{1}$ & $\mathrm{D}_{2}$ & $\mathrm{D}_{3}$ & $\mathrm{D}_{4}$ & $\mathrm{D}_{5}$ & $\mathrm{D}_{6}$ \\
\hline \multirow{2}{*}{2.82} & 160258 & 388457 & 626570 & 396696 & 408125 & 200426 \\
& $(12.01)$ & $(7.61)$ & $(9.47)$ & $(9.76)$ & $(10.43)$ & $(9.91)$ \\
\hline \multirow{2}{*}{5.23} & 212537 & 422447 & 632142 & 408163 & 416579 & 202598 \\
& $(8.00)$ & $(9.43)$ & $(9.72)$ & $(8.83)$ & $(9.57)$ & $(10.61)$ \\
\hline \multirow{2}{*}{11.51} & 420268 & 482370 & 728044 & 780236 & 636698.37 & 520588 \\
& $(8.01)$ & $(8.83)$ & $(10.10)$ & $(9.31)$ & $(9.48)$ & $(10.80)$ \\
\hline \multirow{2}{*}{22.81} & 463451 & 504022 & 761698 & 796854 & 616479 & 560046 \\
& $(9.85)$ & $(9.65)$ & $(9.50)$ & $(9.49)$ & $(9.56)$ & $(9.32)$ \\
\hline
\end{tabular}

Table 3

THE INFLUENCE OF WATER HARDNESS ON LIPASE ACTIVITY OF DIFFERENT DETERGENTS 


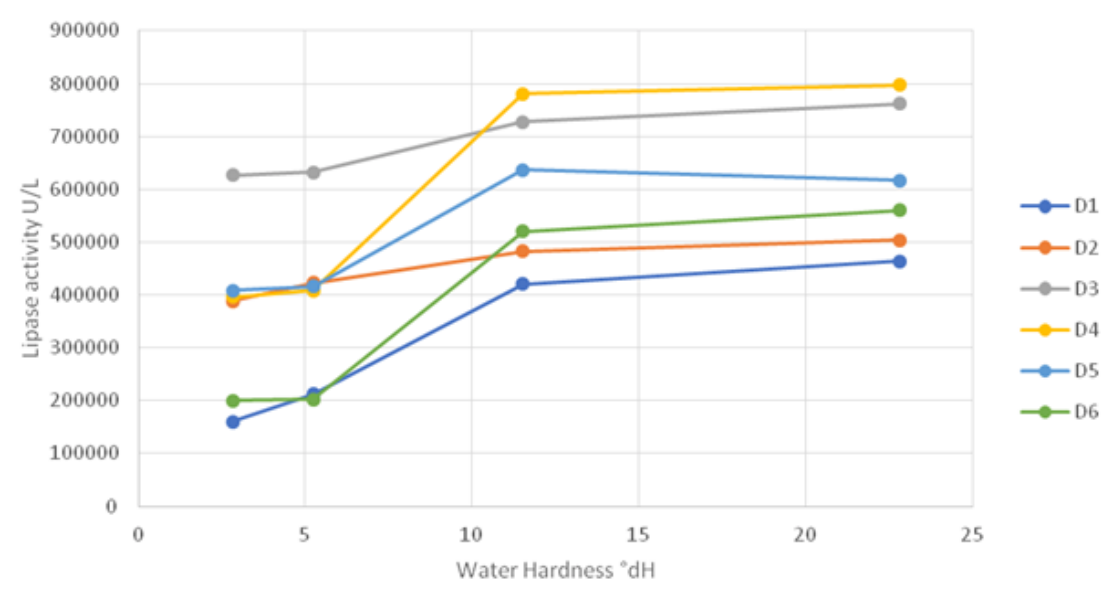

Fig. 4. Water hardness influence on lipolytic activity of different detergents

extremely important in the case of lipid-containing pharmaceutical products or foodstuff in emulsified form, the control of digestion by pancreatic lipase of lipid droplets in the intestinal tract raising the issue of the addition of chelants which are suitable for use in vivo such as lysolecithin, and $\beta$-lactoglobulin [26] or cosurfactants such as Tween 20 [27].

A study by Hu Metal in 2010 shows that there is a minimal concentration of $\mathrm{Ca}^{2+}$ in the environment that is required for the lipase enzyme activity, thus, in the absence of $\mathrm{Ca}^{2+}$, the enzymatic activity is $<12 \%$, while at a concentration of $20 \mathrm{mM} \mathrm{Ca}{ }^{2+}$ lipase activity is higher than 95\% [26].

In vivo the influence of calcium ions on lipase activity also depends on the nature of the hydrolyzed substrate: in the case of short chain fatty acids (eg milk triglycerides), $\mathrm{Ca}^{2+}$ does not activate lipase because the resulting soaps are water soluble, the activating effect being only for the triglycerides of long-chain saturated fatty acids as is the case of sunflower oil triglycerides (Emulsio oleosa being used as the substrate in the determination) or unsaturated and omega 3 or 6 polyunsaturated fatty acids [28].

The enzymatic process catalyzed by lipases and phospholipases is extremely complex - besides the hydrolysis reactions of triglycerides and phospholipids, they also catalyze transacylating and transphosphorylation reactions [29]. Lipases are ubiquitously spread enzymes in nature, but only those produced by microorganisms are used in the manufacture of detergents, cosmetics, surfactants, etc. [30]. To eliminate the shortcomings of microbial cultures (low production yield and hard to be controlled industrially), recombinant heterologous proteins in a host system technique are currently applied [31] .
Water hardness influence on the proteolytic activity of detergents

The results obtained in determining the proteolytic activity are presented in table 4.

From figure 5 , it is observed that detergent $D_{2}$ practically has no proteolytic activity and that the enzymatic activity depends on the hardness of the water - the higher the water hardness the highest the enzymatic activity of the analyzed detergents, the difference between the proteolytic enzymatic activity at the extreme hardness values being statistically significant $(p<0.01 *)$.

Proteases are enzymes active in vivo over a very wide $p \mathrm{H}$ range - from pepsin active in stomach $(p H=1.5-3.0)$ to trypsin and alkaline-active chymotrypsin, thus obtaining commercially active proteolytic enzymes at $\mathrm{pH}=8$ is not an impediment, but proteases have to be stabilized to prevent inactivation (proteolysis) of other enzymes in detergents. Manufacturers recommend either reducing the water content of detergents or adding stabilizers such as borate/propylene glycol. Since numerous proteases contain calcium in the active site and the added anti-scaling agents can eliminate calcium, its presence in the wash water will increase proteolytic activity [32, 33].

A study by Stoner MR etal shows that calcium ion binding on the protein structure, as with amylases, increases the stability of enzymes and calcium chelators, by forming micelle aggregates, compete with the enzyme for binding $\mathrm{Ca}^{2+}$. In this competition for $\mathrm{Ca}^{2+}$ binding, account mustbe taken on the stronger interactions between the protein structure and the calcium ion as compared to chelates, but also that chelating agents are in much higher

\begin{tabular}{|l|l|l|l|l|l|l|}
\hline \multirow{2}{*}{$\begin{array}{c}\text { Water hardness } \\
(\text { 'dH) }\end{array}$} & \multicolumn{6}{|c|}{ Protease activity } \\
\cline { 2 - 7 } & D1 & D2 & D3 & D4 & D5 & D6 \\
\hline \multirow{2}{*}{2.82} & 35192 & 9231 & 63462 & 39038 & 25385 & 24808 \\
& $(7.23)$ & $(20.07)$ & $(8.63)$ & $(10.90)$ & $(11.64)$ & $(11.67)$ \\
\hline \multirow{2}{*}{5.23} & 34904 & 12779 & 30577 & 31442 & 21346 & 30865 \\
& $(12.96)$ & $(11.39)$ & $(7.16)$ & $(8.44)$ & $(9.30)$ & $(8.70)$ \\
\hline \multirow{2}{*}{11.51} & 66923 & 17596 & 75288 & 90865 & 628845 & 88269 \\
& $(8.43)$ & $(20.12)$ & $(12.68)$ & $(9.30)$ & $(12.86)$ & $(10.56)$ \\
\hline \multirow{2}{*}{22.81} & 115385 & 20192 & 172789 & 169039 & 130962 & 130962 \\
& $(8.27)$ & $(18.06)$ & $(13.55)$ & $(7.42)$ & $(11.81)$ & $(9.52)$ \\
\hline
\end{tabular}

Table 4

THE INFLUENCE OF WATER HARDNESS ON PROTEASE ACTIVITY OF DIFFERENT DETERGENTS 


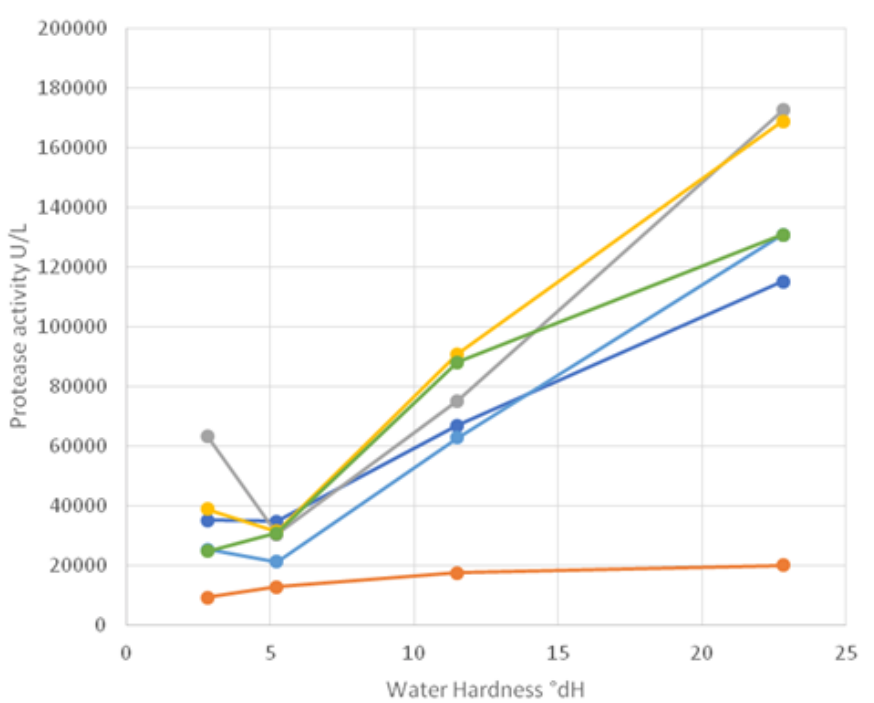

concentrations than enzymes in detergents, therefore the authors recommend addition of $\mathrm{CaCl}_{2}$ in concentrations of $10^{-5} \mathrm{M}$ in the detergent composition required for proteolytic activity [34].

The role of proteases in detergents is to remove stains of biological origin [35]; determining the effectiveness of detergents in removing stains is done by visual methods (in the case of colored stains - blood, cocoa), turbidity, densitometric or colorimetric methods. However, it is important that detergents containing enzyme proteases are not recommended for use in wool and silk fabrics because they can irreversibly degrade the secondary keratin structure $[36,37]$.

A review from 2017 identifies detergents, and especially enzyme detergents, as a pathognomonic cause of atopic dermatitis, causing skin dehydration, skin pH modification, proinflammatory cytokine release and even mediated lgE hypersensitivity [38]. The market for enzyme detergents has much evolved - if in the 1970s type I, IgE mediated allergies were fairly prevalent especially in people with atopic terrain, the prevalence of these allergies nowadays is rare, caused by long exposure or high concentrations of detergent (asthma and allergies to workers in the detergents industry - occupational hazard) $[39,40]$.

\section{Conclusions}

The enzymatic activity of washing detergents is clearly influenced by temperature and various water quality. Higher water hardness significantly influences the lipase and protease activity in detergent, while amylolytic activity does not show significant changes.

Acknowledgment: The authors thank SC SITRONIC SRL for the technical assistance provided by the design and realization of $U 1$ Ultrathermostat Water Bath.

\section{References}

1.BELLISSENT-FUNEL, M.C., HASSANALI, A., HAVENITH, M., HENCHMAN, R., POHL, P., STERPONE, F., VAN DER SPOEL, D., XU, Y., GARCIA, A.E., Chem Rev., 116, no. 13, 2016, p. 7673

2.NIYONZIMA, F.N., MORE, S.S., Appl Biochem Biotechnol., 174, no. 4, 2014, p. 1215

3.NIYONZIMA, F.N., MORE, S.S., J Basic Microbiol., 55, no. 10, 2015, p. 1149

4.KOGAWA, A.C., CERNIC, B.G., DO COUTO, L.G.D., SALGADO, H.R.N., SPJ., 25, no. 6, 2017, p. 934

5.CHAUHAN, M., CHAUHAN, R.S., GARLAPATI, V.K., Biomed Res Int., 2013, p. 374967

6.GOTOH, K., HORIBE, K., MEI, Y., TSUJ ISAKA, T., J Oleo Sci., 65, no. 2, 2016, p. 123
Fig. 5. Water hardness influence on protease enzymatic activity of different detergents

7.GOTOH, K., HARAYAMA, K., HANDA, K., Ultrason Sonochem., 22, 2015, p. 412

8.PINTO, I.S., NETO, I.F., SOARES, H.M., Environ Sci Pollut Res Int., 21, no. 20, 2014, p. 11893

9.MARTINS, J.G., NETO, I.F., PINTO, I.S., SOARES, E.V., BARROS, M.T., SOARES, H.M., J Environ Sci Health A Tox Hazard Subst Environ Eng., 49, no. 3, 2014, p. 344

10.BIANCO, V., FRANZESE, G., Phys Rev Lett., 115, no. 10, 2015, p. 108101

11.SINDHU, R., BINOD, P., MADHAVAN, A., BEEVI, U.S., MATHEW, A.K., ABRAHAM, A., PANDEY, A., KUMAR, V., Bioresour Technol., 245, 2017, p. 1740

12.MEHTA, D., SATYANARAYANA, T., Front Microbiol., 7, 2016, p. 1129 13.ALOULOU, A., PUCCINELLI, D., DE CARO, A., LEBLOND, Y., CARRIÈRE, F., Biochim Biophys Acta., 1771, no. 12, 2007, p. 1446

14.FATIMA, S., AJMAL, R., BADR, G., KHAN, R.H., Cell Biochem Biophys., 70, no. 2, 2014, p. 759

15.*** European Pharmacopoeia, 2013, $8^{\text {th }}$ Edition, p. 2661

16.SITARU, A., TOHATI, A., POP, A.M., BICA, C., Rev. Chim. (Bucharest), 68, no. 12, 2017, p. 2984

17.SIDDIQUI, A., KAMAL, M., AYATOLLAHI, S.A., ALI, M., AHMED, M., Iranian J ournal of Pharmaceutical Research, 16, no. 3, 2017, p. 1141 18.SEYHAN, F., TIJ SKENS, L.M.M., EVRANUZ, O., J ournal of Food Engineering, 52, no. 4, 2002, p. 387

19.MALEKABADI, S., BADOEI-DALFARD, A., KARAMI, Z., Int J Biol Macromol., 109, 2017, p. 389

20.KANEKAR, P.P., NILEGAONKAR, S.S., SARNAIK, S.S., KELKAR, A.S., Bioresour Technol., 85, no. 1, 2002, p. 87

21.CHOUDHARY, V., J. Acad. Indus. Res., 1, no. 6, 2012, p. 301

22.GHOLLASI, M., GHANBARI-SAFARI, M., KHAJ EH, K., Enzyme Microb

Technol., 53, no. 6-7, 2013, p. 406

23.YADAV, J.K., Int J Biol Macromol., 51, no. 1-2, 2012, p. 146

24.LEVEQUE, E., JANECEK, S., HAYEA, B., BELARBI, A., Enzyme and Microbial Technology, 26, 2000, p. 3

25.SABOURY, A.A., KARBASSI, F., Thermochimica Acta., 362, no. 1-2, 2000, p. 121

26.HU, M., LI, Y., DECKER, E.A., MC CLEMENTS, D.J., Food Hydrocolloids, 24, no. 8, 2010, p. 719

27.PAUN, I., IANCU, V.I., CRUCERU, L., NICULESCU, M., CHIRIAC, F.L., Rev. Chim.(Bucharest), 69, no. 1, 2018, p. 27

28.TERO-VESCAN, A., VANCEA, S., HUTANU, A., BORKA-BALÁS, R., DOBREANU, M., Farmacia, 63, no. 4, 2015, p. 504

29BORRELLI, G.M., TRONO, D., IntJ Mol Sci., 16, no. 9, 2015, p. 20774 30.BANCERZ, R., Postepy Biochem., 63, no. 4, 2017, p. 335

31.WANG, H.K., SHAO, J., WIE, Y.J ., ZHANG, J., QI, W., Food Technol. Biotechnol., 49, 2011, p. 96

32.MECHRI, S., BEN ELHOUL BERROUINA, M., OMRANE BENMRAD, M., ZARAÎ J AOUADI, N., REKIK, H., MOUJ EHED, E., CHEBBI, A., SAYADI, S., CHAMKHA, M., BEJAR, S., JAOUADI, B. Int J Biol Macromol., 94, 2017, p. 221

33.PATIL, U., MOKASHE, N., CHAUDHARI, A., Prep Biochem Biotechnol., 46, no. 1, 2016, p. 56 
34.STONER, M.R., DALE, D.A., GUALFETTI, P.J ., BECKER, T., RANDOLPH, T.W., Biotechnol Prog., 21, no. 6, 2005, p. 1716

35.SALANTA, L.C., PAUCEAN, A., TOFANA, M., MAN, S., POP, C., J ournal of Agroalimentary Processes and Technologies, 21, no. 2, 2015, p. 186 36.NIYONZIMA, F.N., MORE, S., Prep Biochem Biotechnol., 45, no. 3 , 2015, p. 233

37.COSTAN VV, POPESCU E, SULEA D, STRATULAT IS. A New Indication for Barbed Threads: Static Reanimation of the Paralyzed Face. J Oral Maxillofac Surg. Vol. 76, nr. 3, 2018, p. 639-645, doi: 10.1016/ j.joms.2017.07.176.
38.BOOTHE, W.D., TARBOX, J.A., TARBOX, M.B., Adv Exp Med Biol., 1027, 2017, p. 21

39.BASKETTER, D., BERG, N., KRUSZEW SKI, F.H., SARLO, K., CONCOBY, B., J Immunotoxicol., 9, no. 3, 2012, p. 320

40.SARLO, K., KIRCHNER, D.B., Curr Opin Allergy Clin Immunol., 2, no. 2, 2002, p. 97

Manuscript received: 21.03 .2018 